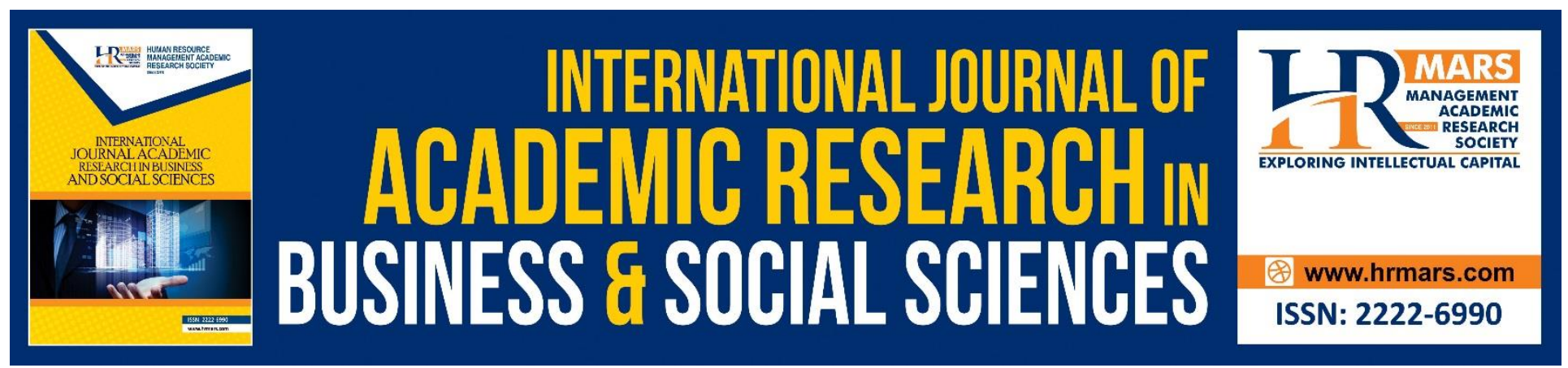

\title{
Current Trends and Opportunities for Halal Restaurants in Thailand: A Conceptual Framework
}

Wannasiri Wannasupchue, Mohhidin Othman, Ungku Fatimah Ungku Zainal Abidin, Farah Adibah Che Ishak and Siti Fatimah Mohamad

To Link this Article: http://dx.doi.org/10.6007/IJARBSS/v9-i1/5392

DOI: $\quad 10.6007 /$ IJARBSS/v9-i1/5392

Received: 11 Dec 2018, Revised: 19 Jan 2019, Accepted: 27 Jan 2019

Published Online: 04 Feb 2019

In-Text Citation: (Wannasupchue, Othman, Abidin, Ishak, \& Mohamad, 2019)

To Cite this Article: Wannasupchue, W., Othman, M., Abidin, U. F. U. Z., Ishak, F. A. C., \& Mohamad, S. F. (2019). Current Trends and Opportunities for Halal Restaurants in Thailand: A Conceptual Framework. International Journal of Academic Research in Business and Social Sciences, 9(1), 235-247.

Copyright: (C) 2019 The Author(s)

Published by Human Resource Management Academic Research Society (www.hrmars.com)

This article is published under the Creative Commons Attribution (CC BY 4.0) license. Anyone may reproduce, distribute, translate and create derivative works of this article (for both commercial and non-commercial purposes), subject to full attribution to the original publication and authors. The full terms of this license may be seen

at: http://creativecommons.org/licences/by/4.0/legalcode

Vol. 9, No. 1, 2019, Pg. 235 - 247

http://hrmars.com/index.php/pages/detail/IJARBSS

JOURNAL HOMEPAGE

Full Terms \& Conditions of access and use can be found at http://hrmars.com/index.php/pages/detail/publication-ethics 


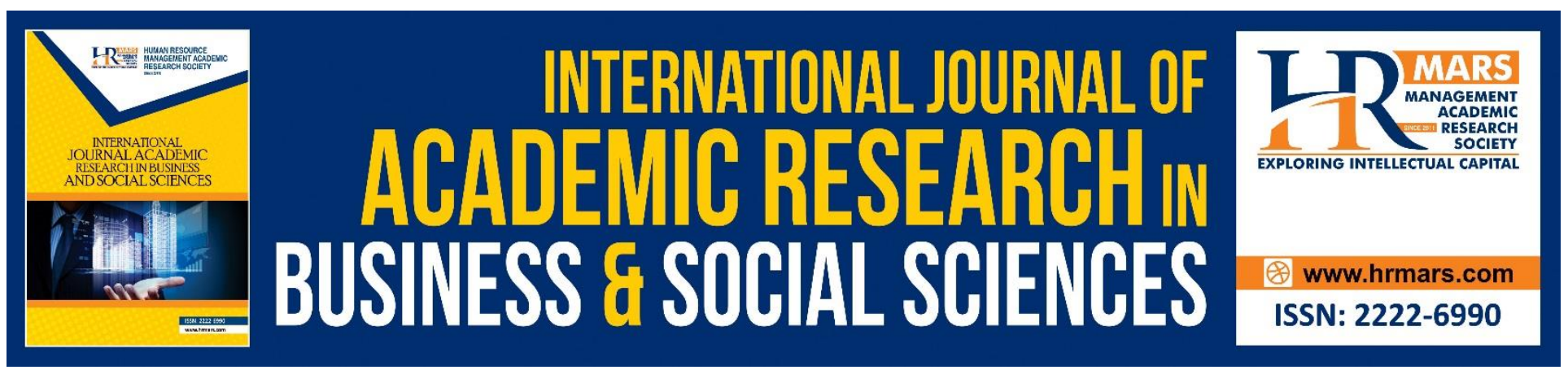

\title{
Current Trends and Opportunities for Halal Restaurants in Thailand: A Conceptual Framework
}

\author{
Wannasiri Wannasupchue, Mohhidin Othman, Ungku Fatimah \\ Ungku Zainal Abidin, Farah Adibah Che Ishak and Siti Fatimah \\ Mohamad \\ Department of Food Service and Management, Universiti Putra Malaysia, 43400, Selangor \\ Malaysia
}

\begin{abstract}
The food and beverage business is a vital part of the tourism sector. This was among the top five sources of income for Thailand, worth 448 billion baht in 2015, and may continually increase due to the expansion of the tourism industry. More than 20 million tourists visit Thailand every year, so tourist attractions should have a variety of restaurants that should not only have food that tastes great, but also excellent service and hygienic conditions. Therefore, halal certification for food services is required when halal tourism becomes significant. Having halal status would provide a competitive advantage and accommodate the expanding market share among Muslim and nonMuslim customers. However, there is an emerging opportunity for halal restaurants, with the number of halal establishments in some regions of Thailand being inadequate for people who want to try halal food. Furthermore, some halal restaurants run by Muslim owners are not certified by a halal certification body. The objectives of this paper are to review literature on halal certification and to provide recommendations and guidelines on the opportunities in establishing a halal restaurant in Thailand. Finally, we will look into the importance of the halal status in attracting more Muslim and non-Muslim restaurant owners who have not been certified halal yet to apply for the certification.
\end{abstract}

Keywords: Islamic dietary, Halal certification, Dining experiences, Tourism industry, Thailand

\section{INTRODUCTION}

Muslims must follow Islamic rules in their daily routine, and all of these rules come under Shari'a law that covers the scope of human living, including clothes, food and beverages, and pattern of living (Aslan and Aslan 2016; Mohsin et al. 2016). The definition of halal is lawful and permitted (Aslan and Aslan 2016; Marzuki et al. 2012). Hence, halal food must be prepared and processed in line with strict Islamic dietary rules, from farm to fork. Presently, the world's population is approximately 7.5 billion, the majority of whom are Muslim (Cleland 2013; Thomson Reuters 2013; Henderson 2016). The 
number is enormous and may gradually increase to around 2.2 billion by 2030 globally. Also, tourists from this group would be considerable because of their immense number. For example, tourists from Arab Gulf countries have spent US\$20 billion annually for travel (Thomson Reuters 2013). To attract Muslim tourists, Thailand must provide facilities such as mosques, accommodation, and food and drinks prepared in accordance with the Quran. All businesses concerned with tourism, especially halal restaurants, have to ensure they are officially certified halal to raise customer trust (Karoui and Khemkhem 2016). Furthermore, managers of 33 restaurants with halal certification in Malaysia suggested that halal status contributes to customers' positive attitude and an increase in income (Marzuki et al. 2012). Besides, non-Muslims concerned about their health are also a possible target market because of their positive attitude and acceptance of halal food (Mathew et al. 2014).

Tourism is the foremost factor driving the economy in Thailand, and comprises hotels, restaurants, tourism agencies and souvenir shops (Polyorat and Sophonsiri 2010; Chavarria and Phakdee-auksorn 2017). More than 20 million tourists visit Thailand annually and most of them come from countries such as China, South Korea, Malaysia, India, the United Kingdom, the USA and Germany (Department of Tourism 2016). This has established the Thai tourism sector as one of the top five sources of income for the nation, contributing 448 billion baht in 2015 , which looks only to increase. Thus, it is assumed that there are emerging opportunities to gain more revenue via this sector. With dining being a crucial part of tourism, it is no wonder that Thai cuisine is well known around the world. Tom yum kung, Pad Thai and Thai green curry with chicken are famous dishes that tourists love. In addition, more restaurants should be established to attract tourists while the food should taste good and be complemented by excellent service.

The definition of food is something that is taken or swallowed by a human body through the mouth. Food should not be toxic to the body because food poisoning could cause disease and some could be seriously affected. Consequently, restaurants should maintain a certain standard in food quality through the implementation of the Good Manufacturing Practice (GMP) and halal certification, which ensures the necessary standards for Muslims under Islamic dietary rules are followed. This encompasses all levels of food production, from farm to fork. Even though halal food is generally only a standard for Muslims, nowadays, this food has become a more acceptable standard for sanitation and hygienic conditions attractive among non-Muslims customers as well. Halal food is very important to attract Muslim tourists as they must spend money on food and drinks during their trips and if they are satisfied, it is likely they will repeat their visit. Therefore, tourist attractions must provide quality halal restaurants to cater to Muslim tourists. While the total number of halal restaurants in Thailand is 581, such establishments in the northeast and eastern regions number fewer than 20. It is said that this is not enough to support tourists who want to try Muslim food. Some halal restaurants run by Muslims don't pursue halal certification, either. Hence, they cannot display the official halal certification logo in a visible place and Muslim tourists are less inclined to trust their food quality. Encouraging these restaurants to pursue halal certification would increase the quality of the restaurant as well. This could attract more Muslim tourists, to the advantage of the Thai economy. 
This study is aimed at introducing concepts of Islam's dietary rules and steps needed to apply for halal certification in Thailand. The study will look at data from various sources including previous studies, articles, books and documents to bring about a better understanding of current trends and opportunities on how to start up halal establishments in Thailand. Next, the paper presents the conceptual framework of the study. This framework provides research questions and identifies the gap between two types of halal restaurants -- certified and non-certified. Last of all, the conclusion will summarize and furnish a direction for halal restaurant owners targeting Muslim as well as nonMuslim customers.

\section{LITERATURE REVIEW} Islamic Dietary Rules

Islamic dietary rules are a set of daily living rules related to food and drinks for Muslims. Muslims have the scope for human intrusion under Shari'a law (Mohsin et al., 2016). They must strictly follow the rules not only when it comes to food but also in clothes they wear, amusement and way of living. These rules always mention the Arabic word that represents halal (حلال) (Battour and Ismail 2015; Sumaedi and Yarmen 2015; Alam and Sayuti 2011), which refers to permitted and lawful under Shari'a as stated in the Quran. In addition, another word that is always mentioned with halal is "Toyyib", referring to goodness and purity (Mohamad and Backhouse 2014). Thus, halal certification requirements must be set up under the scope of Shari'a and Toyyiban aspects to ensure halal quality (Ahmad et al. 2017; Ibrahim and Othman 2014). Halal food production involves ingredients, food additives and production processes that must follow Shari'a law (Abdul et al. 2009; Wan-hassan and Awang 2009; Haque et al. 2015). Besides, halal food operators must be aware of food preparation to raise customers' confidence in the hygienic conditions, safety and sanitation involved in the production of the food.

Some foods such as pork, dead animals, blood and alcohol are not approved under Islamic guidelines and are called haram or forbidden foods (Ismoyowati 2015; Mohamad and Backhouse 2014). Haram is one of the major words used in Islamic dietary rules. The meaning of this Arabic word is "not allowed, unlawful, illegal and forbidden". There are four categories of prohibited food and beverages, which consists of (i) food or drinks that are unclear with the Quran, (ii) food or drinks that contain any prohibited ingredients, (iii) food or drinks that harms the human body and (iv) food or drinks that are impure and suspicious (Al-Qaradawi 1999; Mohamad and Backhouse 2014). So, halal food production must be aware of that what is haram goes against Islamic requirements. Regarding Islamic dietary rules, halal restaurants must be certified by official halal bodies to ensure that all components in food production follow Shari'a rules. Even though the process of halal certification differs from country to country, the main aims of halal certification remains the same.

\section{Halal Certification in Thailand}

Halal certification was verified and endorsed by the Central Islamic Committee of Thailand (CICOT). The committees were established by co-operators such as Shari'a experts and Islamic rules experts, food scientists and governments. Their responsibilities are to determine and announce regulations of Thai halal standards to the Provincial Islamic Committees. All Provincial Islamic Committees must 
follow CICOT regulations and are responsible for halal issues in their region of Thailand. These Thai halal standards usually update and adjust regulations in line with international Islamic standards. Figure 1 presents three sections of halal certification divided into application preparation, audit program, and endorsement and certification (The Central Islamic Council of Thailand, 2016). Furthermore, restauranteurs who want halal certification are required to take several steps. Firstly, halal restaurant owners must submit an application to the CICOT office. Then, CICOT will provide a halal training program for new business owners. Next, a business holder pays a fee based on CICOT's rate. After that, an audit team assigned by CICOT will inspect sites and report information to the halal committee. After that, a board meeting is held to evaluate. Finally, a certified restaurant owner can display the halal logo visibly at its premises.

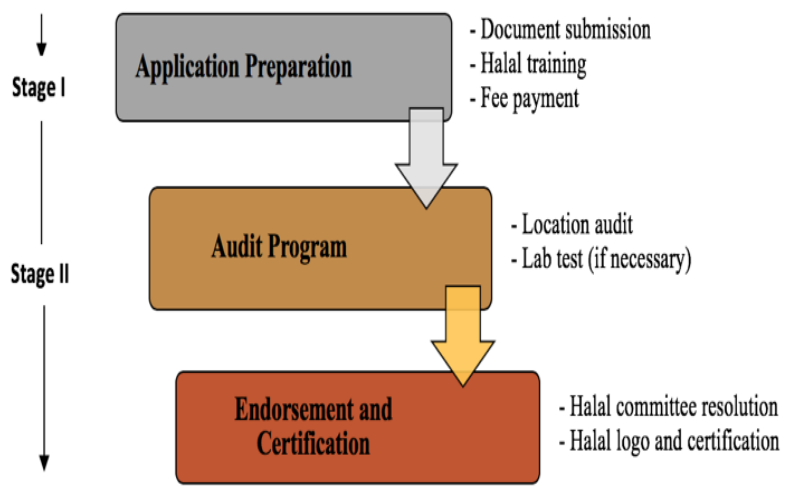

Figure 1. Steps to halal certification in Thailand

(Source: The Central Islamic Council of Thailand 2016)

Also, some business owners based farther from the capital city, Bangkok, such as in the north, south, and northeast of the country, can submit their applications to Provincial Islamic Committee branches closer to them to authorize their halal certification under the auspices of CICOT. Nevertheless, while each country has different halal standards and requirements, certification must be performed in line with Shari'a law and the Quran and Sunnah as references. Halal certification bodies are tasked with monitoring and approving halal certification. Similarly, other countries have certifying bodies. For example, the halal certification body in Malaysia is Jabatan Kemajuan Islam Malaysia (JAKIM), Majlis Ulama Indonesia (MUI) in Indonesia, Majlis Ugama Islam Singapore (MUIS) in Singapore, and Halal Certification Agency (HCA) in Vietnam (Othman et al. 2016).

\section{Dining Experiences}

Most people prefer to dine outside because they do not have enough time to cook at home and some want to gain a new experiences or taste something new. Tourists are a valuable target group for culinary businesses. They provide a great opportunity for the food and beverage business, especially restaurants that prepare and sell food not only to locals but tourists as well. Restaurants should provide quality dining services and delicious dishes as a positive dining experience will contribute to 
tourists' impression of the country, making them more likely to return to visit. The Ministry of Tourism and Sport, Thailand, (2016) reported that Thai food (66.8\%) ranked second in tourist satisfaction during their travels across Thailand. Furthermore, gastronomy or culinary tourism is a new trend and has become widely known in China (Quan and Wang 2004; Huang 2017). Consequently, food not only provides sustenance for the human body but also represents culture via a special taste or unique food decoration. These factors surely motivate tourists to look for an excellent dining experience. Based on previous studies, factors of dining experiences can be divided into internal and external factors, presented in Figure 2 (Wijaya et al. 2013; Chen et al. 2016; Mak et al. 2012). Internal factors include human demographics, traveling style and past experiences, which create a good or bad memory of a dining experience. These could also be a cause of bias when choosing a restaurant. For example, people who prefer spicy food will look for restaurants that serve hot dishes. Hence, people's cultural backgrounds and their experiences determine their food selection.

In addition, external factors also contribute to experience outcomes. The recent study states that external factors include food quality, food prices, chef's image, social and restaurant ambiance (Huang 2017; Wijaya et al. 2013; Chen et al. 2016). It is aware that, for instance, food and beverages are sold at higher prices at some tourist attractions. This causes tourists to consider prices as well as quality of the food. (Chen et al. (2016) confirmed that the relationship between tourists' satisfaction and a chef's image is valuable to overall dining experiences. They studied how Teppanyaki chefs could motivate Taiwanese tourists, with results showing that the tourists felt more positive when a chef, much like an ambassador for the nation's dining culture, showed off his cooking skills. Moreover, key factors attracting diners include a restaurant's environment, such as lighting, music, color and decoration (Babin et al. 2003; Cho and Lee 2017; Tantanatewin and Inkarojrit 2018). Tantanatewin and Inkarojrit (2018) mentioned that color can stimulate customers' emotions, for example customers become more excited when surrounded by warm colors than cooler tones. The type of restaurant is also an essential factor in attracting customers as decoration and color can encourage a customer to walk into a restaurant. Both internal and external factors affect the customer's satisfaction and perception, contributing to their overall experience outcomes. The experience outcomes may be positive, leading the customer to spread the word widely through communication with others, whereas it may be negative, and the customer will complain about his experience and vow never to return. Therefore, positive dining experiences influence higher income and attract more customers. 


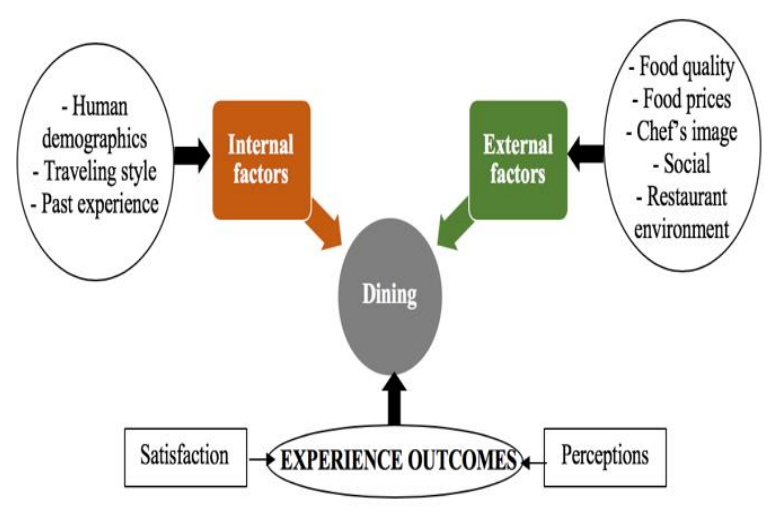

Figure 2. The Factor of Dining Experiences

In addition to internal and external factors, some customers, namely Muslims, emphasize quality certification. They are more likely to choose a restaurant if they can be guaranteed a satisfactory dining experience. Most look for the halal logo before walking into a restaurant. This is an initial factor that encourages one to choose a restaurant. To assure diners of a good experience, restaurant owners can apply for the halal certification and follow the requirements. After that, they can display the halal certification logo at their premises. This will provide them a competitive advantage and expand their market share.

\section{OPPORTUNITIES FOR HALAL RESTAURANTS IN THAILAND}

Halal restaurants are establishments that follow Islamic rules, including in its food preparation process. These restaurants cater not only to Muslim customers but also non-Muslims wanting to try halal food. Halal food is linked to healthy consumption as halal food operators are forbidden from using ingredients such as alcohol, pork and toxic substances that contaminate meals (Ismoyowati 2015; Salman and Siddiqui 2011). The Tourism Authorism Authority of Thailand (2015) reported that the total number of halal restaurants in Thailand was 581, consisting of 306 in the central region, 146 in the south, 111 in the north, 11 in the northeast and 7 in the east (Table 1).

The Tourism Council of Thailand (2017) stated that the northeast region was fast-becoming popular among foreign tourists. However, the number of halal restaurants in this region numbered at fewer than 20, including non-certified halal restaurants, a number that is inadequate to support growing demand. Certified halal refers to a restaurant in which all food preparation and production processes have been examined and endorsed by CICOT. After being certified, the restaurant owners can display the halal logo in front of their restaurants. Another category is assumed to be a halal restaurant run by Muslim owners that is not certified and no application has been made to CICOT to guarantee its food production processes follow Islamic rules. However, both such restaurants contribute to tourist satisfaction. Thus, CICOT must encourage non-certified halal restaurants to apply for certification to build higher customer trust. 
INTERNATIONAL JOURNAL OF ACADEMIC RESEARCH IN BUSINESS AND SOCIAL SCIENCES

Vol. 9, No. 1, Jan, 2019, E-ISSN: 2222-6990 @ 2019 HRMARS

Table 1 Number of Halal Restaurants

\begin{tabular}{ll}
\hline \hline Region & Number of Halal Restaurants \\
\hline Central & 306 \\
\hline South & 146 \\
\hline North & 111 \\
\hline Northeast & 11 \\
\hline East & 7 \\
\hline Total & 581 \\
\hline \hline
\end{tabular}

The food and beverage industry is fundamental to modern living and should be highly accessible to tourists. Comfort and convenience are considerable factors that tourists require. Tourist attractions must provide such facilities to satisfy tourists. Based on the researchers' observations, Muslim tourists who visit the northeastern region of Thailand must bring their own meals on their travels. Similarly, Wan-hassan and Awang (2009) stated that Muslim tourists in New Zealand also prepared meals from their country. If a tourist feels uncomfortable about finding an appropriate place to eat, they would not travel to that area. When tourists arrive at their destination, they must find appropriate food. This creates opportunities to provide various types of food. If they find that food is convenient and are satisfied, then this encourages more tourists, and more income opportunities are created. Hence, halal restaurants are considered a novel phenomenon as there is less competition in the northeast and eastern regions. Also, the competitive benefits for a business owner in both areas still abound.

Last of all, the halal logo appears as a signal to communicate to customers. For Muslim customers, halal restaurants provide dishes made following Shari'a rules while non-Muslim customers are assured of a hygienic dish that is good for their wellbeing. After all the effort to gain halal status, restaurant owners can then attract Muslim tourists. This is a good opportunity for business owners.

\section{A CONCEPTUAL FRAMEWORK OF THE STUDY}

As mentioned, there appears to be a large number of halal restaurants in most regions in Thailand except the northeast and east. Muslim restaurants are mainly divided into two types: certified halal and non-certified halal. Both are run by Muslim owners, who prepare and cook the food in a similar fashion. While some establishments apply for halal certification, some are not interested in applying for the certification. So, the authors have identified the gaps between certified and halal and noncertified halal restaurants (Figure 3). These contribute to the research questions below:

1) What is the difference in owners' attitude between halal certification and non-certification for restaurants in Thailand?

2) What are the factors that result in the success of certified halal restaurants?

3) What are the factors that encourage non-certified restaurants to apply for halal certification? 
Thailand's halal certification body plays a major part in authorizing halal certification. Their responsibilities are planning, setting, advising, endorsing and monitoring the halal status. They play a vital role in driving halal businesses to reach success with the halal certification. This has brought about the research questions as follows:

1) What role does Thailand's halal certification body play to encourage non-certified restaurants to apply for halal certification?

2) What are the strategies to support non-certified halal restaurants?

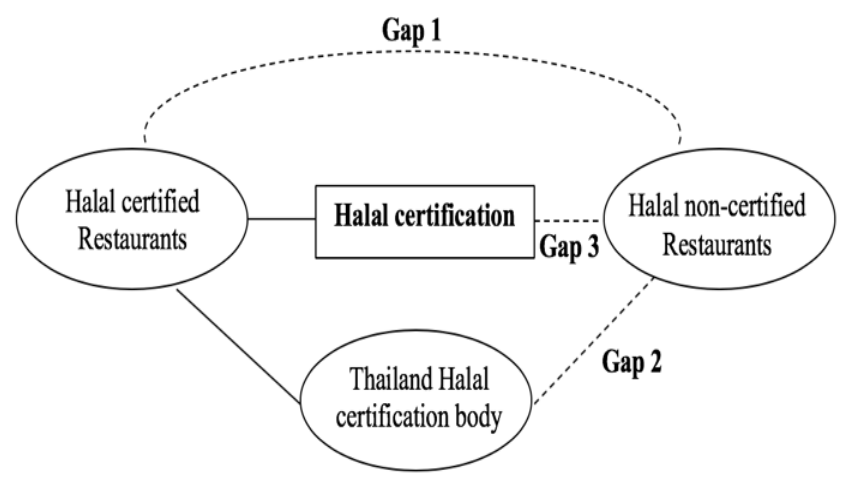

Figure 3. A Conceptual Framework of the Study

Further research could look into these issues and identify the challenges and factors that could increase the number of certified halal restaurants in Thailand. The previous study suggested that their attitude, acculturation, halal certification quality, perceived behavioral control and understanding of Islamic rules could attract Muslim and non-Muslim customers (Ayyub 2015; Haque et al. 2015). Uansa-ard and Binprathan (2018) mentioned that a business owner should work with religious standards bodies within and outside ASEAN countries to establish much needed facilities for Muslim tourists.

\section{METHODOLOGY}

Research should be undertaken by gathering the opinions and experiences of a study participant. This qualitative study will provide insight into human thought recorded in words (Creswell and Poth 2018). To better understand the issue, a researcher must understand the topic in depth. Key points concerning why some non-certified restaurants don't pursue halal certification and what factors could encourage them to do so will be touched on. The participants can be restaurant owners willing to convey their experiences to a researcher. Therefore, interviews are the most suitable method to delve into a respondent's mind as they can explain their thoughts during an interview, and a researcher can observe their actions, at the end combining the research findings with interview data. Apart from that, the qualitative study will use the purposive sample technique to select who will be a respondent and who matches well with the purpose of the study. After that, a researcher will analyze the data using thematic analysis as this method will arrange the research findings into the same categories, allowing a researcher to find any correlations in data. Last of all, the findings, presented as a story, can describe clearly the current situation and allow the readers to better 
INTERNATIONAL JOURNAL OF ACADEMIC RESEARCH IN BUSINESS AND SOCIAL SCIENCES

Vol. 9, No. 1, Jan, 2019, E-ISSN: 2222-6990 @ 2019 HRMARS

understand it. Hence, a qualitative study is the research method that best suits the conceptual framework of the study mentioned above.

\section{CONCLUSIONS}

The halal tourism trend is likely to expand because of the large population of Muslims worldwide. Muslim tourists are particular about foods that adhere to Islamic dietary rules. This is the key to promoting halal certification and encouraging those without it to get it. Challenges exist but they are worth looking into. The tourism sector, especially the food and beverage industry, can support Muslim tourists by using a halal certification standard to communicate with them. Local and foreign Muslim tourists need assurance that the halal logo means the establishment is certified by Thailand's halal certification body. Therefore, halal certification should act as a measure to guarantee food is prepared in hygienic conditions governed by Islamic principles. The authors would like to suggest that further studies collect data via the qualitative method, such as through face-to-face interviews with owners of both certified and non-certified halal restaurants to identify different factors influencing their decisions. The findings could provide the direction for a restaurant owner or the Thai government to encourage non-certified halal restaurants to apply for halal certification. This could help promote Thailand as a Muslim-friendly locale while influencing and driving the nation's tourism sector and economy.

\section{SIGNIFICANT OF THE RESEARCH}

Land of smile represents Thailand because this country is rich of a beautiful culture and ready to welcome visitors. $90 \%$ of the population in Thailand is Buddhist but this country is also welcome a Muslim tourist. However, they have to provide a facility such as a mosque, a prayer room, a hotel, and a restaurant to support a Muslim tourist. This tourist group is very interesting to attach for driving Thai tourism industry because over all of the world population is Muslim. The facilities preparing such as food and drinks should match with Islamic rules that are very important. Therefore, this research will give a significant in term of theoretical and practical. To begin with theoretical, the main study of this research is identifying the success factors of a halal certified restaurant and the challenges of non-certified halal restaurants for applying a halal certification. The authors would say that the answer from both restaurants would contribute a better understand the current situation in Thailand. The halal authority may bring this research to plan a strategy for increasing the quality of a halal catering nationwide and encourage non-certified halal restaurants to go for halal certification. Look at practical, the businesses related halal tourism is a new phenomenon. People who are looking to own a business have to find a great opportunity that should be low a competition. This research would contribute the points that advantage for marketing planning an add-on value to their restaurants by using a halal logo to communicate with Muslim tourists. Furthermore, the restaurant owners have to understand and apply this theory to improve their restaurants to be certified and it could save their time than the study by themselves.

\section{Acknowledgments}

The authors gratefully recognize The Southeast Asian Regional Center for Graduate Study and Research in Agriculture (SEARCA) for financial support. 
INTERNATIONAL JOURNAL OF ACADEMIC RESEARCH IN BUSINESS AND SOCIAL SCIENCES

Vol. 9, No. 1, Jan, 2019, E-ISSN: 2222-6990 @ 2019 HRMARS

\section{References}

Abdul, M., Ismail, H., Hashim, H., \& Johari, J. (2009). Consumer decision making process in shopping for halal food in Malaysia. China-USA Business Review, 8(9), 40-47.

Ahmad, N. A., Rahman, A. R., Othman, M., \& Abidin, Z. U. F. U. (2017). Critical success factors affecting the implementation of Halal Food Management Systems: Perspective of halal executives, consultants and auditors. Food Control, 74, 70-78.

Al-Qaradawi, Y. (1999). The lawful and the prohibited in Islam (al Halal Wal Haram Fil Islam), trans: Ahmad Zaki, Hammad. Indianapolis, US: American Trust Publications.

Alam, S. S., \& Sayuti, M. N. (2011). Applying the Theory of Planned Behavior (TPB) in halal food purchasing. International Journal of Commerce and Management, 21(1), 8-20, https:// doi.org/10.1108/10569211111111676

Aslan, I., \& Aslan, H. (2016). Halal foods awareness and future challenges. British Journal of Economics, Management \& Trade, 12(3), 1-20.

Ayyub, M. R. (2015). Exploring perceptions of non-Muslims towards halal foods in UK. British Food Journal, 117(9), 2328-2343.

Babin, B. J., Hardesty, D. M., \& Suter, T. A. (2003). Color and shopping intentions: the inter- vening effect of price fairness and perceived affect. Journal Business Research, 56 (7), 541-551.

Battour, M., \& Ismail, N. M. (2015). Halal tourism: Concepts, practises, challenges and future. Tourism Management Perspectives, http://dx.doi.org/10.1016/j.tmp.2015.12. 008

Chavarria, T. C. L., \& Phakdee-auksorn, P. (2017). Understanding international tourists' attitudes towards street food in Phuket, Thailand. Tourism Management Perspectives, 21, 66-73.

Chen, A., Peng, N., \& Hung, K. (2016). Chef image's influence on tourists' dining experiences. Annals of Tourism Research, 56, 128-163.

Cho, J. Y., \& Lee, E. J. (2017). Impact of interior colors in retail store atmosphere on consumers' perceived store luxury, emotions, and preference. Clothing and Textiles Research Journal, 35 (1), 33-48.

Cleland, J. (2013). World population growth; Past, present and future. Environmental and Resource Economics, 55(4), 543-554.

Creswell, W., \& Poth, N. C. (2018). Qualitative inquiry and research design; choosing among five approaches. 4th edition. SAGE Publications.

Department of Tourism. (2016). The tourism situation summary, August. Retrieved August 3, 2018, from https://www.m-society.go.th/article_attach/17862/20033.pdf

Haque, A., Sarwar, A., Yasmin, F., Tarofder, K. A., \& Hossain, A. M. (2015). Non-Muslim consumers' perception toward purchasing halal food products in Malaysia. Journal of Islamic Marketing, 6(1), 133-147.

Henderson, C. J. (2016). Halal food, certification and halal tourism: Insights from Malaysia and Singapore. Tourism Management Perspectives, 19, 160-164.

Huang, J. (2017). The dining experience of Beijing roast duck: A comparative study of the Chinese and English online consumer reviews. International Journal of Hospitality Management, 66, 117129. 
INTERNATIONAL JOURNAL OF ACADEMIC RESEARCH IN BUSINESS AND SOCIAL SCIENCES

Vol. 9, No. 1, Jan, 2019, E-ISSN: 2222-6990 @ 2019 HRMARS

Ibrahim, S., \& Othman, M. (2014). Developing and validating Halal Service Quality Instrument for Malaysian food service establishments: A conceptual paper. Procedia Social and Behavioral Sciences, 130, 400-408.

Ismoyowati, D. (2015). Halal food marketing: A case study on consumer behavior of chicken-based processed food consumption in central part of Java, Indonesia. Agriculture and Agricultural Science Procedia, 3, 169-172.

Karoui, S., \& Khemkhem, R. (2016). To more understanding the "Halal" market and the Islamic consumer-factors affecting the Islamic purchasing behavior. International Journal of Academic Research in Business and Social Sciences, 6(8), 65-99.

Mak, A. H. N., Lumbers, M., Eves, A., \& Chang, K. C. (2012). Factors influencing tourist food consumption. International Journal of Hospitality Management, 31, 928-936.

Marzuki, S. Z. S., Hall, M. C., \& Ballantine, W. P. (2012). Restaurant managers' perspectives on Halal certification. Journal of Islamic Marketing, 3(1), 47-58.

Mathew, N. V., Abdullah, A. R. M. A., \& Ismail, M. N. S. (2014). Acceptance on halal food among NonMuslim consumers. Procedia Social and Behavioral Science, 121, 262-271.

Ministry of Tourism and Sport. (2016). Tourism Economic Review. Retrieved February 15, 2018, from http://www.mots.go.th/ewt_dl_link.php?nid=7789

Mohamad, N., \& Backhouse, C. (2014). A framework for the development of halal food products in Malaysia. The 2014 International Conference on Industrial Engineering and Operations Management Bali, Indonesia.

Mohsin, A., Ramli, N., \& Alkhulayfi, A. B. (2016). Halal tourism: Emerging opportunities. Tourism Management Perspectives, 19, 137-143.

Othman, B., Sharifudin, M. S., \& Bahron, A. (2016). The potential of ASEAN in Halal certification implementation: A review. Pertanika Journal, 24(1), 1-24.

Polyorat, K., \& Sophonsiri, S. (2010). The influence of service quality dimension on customer satisfaction and customer loyalty in the chain restaurant context: A Thai case. Journal of Global Business and Technology, 6(2), 64-76.

Quan, S., \& Wang, N. (2004). Towards a structural model of the tourists experience: An illustration from food experiences in tourism. Tourism Management, 25(3), 297-305.

Salman, F., \& Siddiqui, K., (2011). An exploratory study for measuring consumers' awareness and perceptions towards halal food in Pakistan. Interdisciplinary Journal of Contemporary Research in Business, 3(2), 639-652.

Sumaedi, S., \& Yarmen, M. (2015). Measuring perceived service quality of fast food restaurant in Islamic country: A conceptual framework. Procedia Food Science, 3, 119-131.

Tantanatewin, W., \& Inkarojrit, V. (2018). The influence of emotional response to interior color on restaurant entry decision. International Journal of Hospitality Management, 69, 124-131.

The Central Islamic Council of Thailand. (2016). Announcement of The Central Islamic Council of Thailand, No. 1 (2559). Retrieved May 4, 2018, from http://www.cicot.or.th/ storages/ contents/attachments/3._On_The_requirements_for_certification_process_of_Halal_ products_B.E. 2559..pdf 
The Tourism Authority of Thailand. (2015). Halal check in Thailand. Retrieved May 16, 2018, from https://www.tourismthailand.org/fileadmin/upload_img/Multimedia/Ebrochure/667/ halal.pdf

Thomson Reuters. (2013). State of the global Islamic economy report. Dubai: Global Islamic Economic Summit, 1-214.

Tourism Council of Thailand. (2017). Thailand tourism confidence index. Retrieved May 16, 2018, from http://www.thailandtourismcouncil.org/wp-content/uploads/2017/07/TCT_confiden ce _file_th_2017-06-22_11-19-28.pdf

Uansa-ard, S., \& Binprathan, A. (2018). Creating the awareness of Halal MICE tourism business in Chiang Mai, Thailand. International Journal of Tourism Policy, 8(3), 203-213.

Wan-hassan, M. W., \& Awang, W. K. (2009). Halal food in New Zealand restaurants: An exploratory study. International Journal of Economics and Management, 3(2), 385-402.

Wijaya, S., King, B., Nguyen, T., \& Morrison, A. (2013). International visitor dining experiences: A conceptual framework. Journal of Hospitality and Tourism Management, 20, 34-42. 